\title{
Fusaristatins A and B, Two New Cyclic Lipopeptides from an Endophytic Fusarium sp.
}

\author{
Yoshihito Shiono, Mio Tsuchinari, Keiko Shimanuki, Takeshi Miyajima, \\ Tetsuya Murayama, Takuya Koseki, Hartmut Laatsch, Takayuki Funakoshi, \\ Koji Takanami, Keitarou Suzuki
}

Received: January 12, 2007 / Accepted: April 25, 2007

(C) Japan Antibiotics Research Association

\begin{abstract}
Two new cyclic lipopeptides, fusaristatins A (1) and B (2) were isolated from rice cultures of a Fusarium sp. YG-45 in the course of a screening of endophytic fungi. Their structures of $\mathbf{1}$ and $\mathbf{2}$ were determined by spectroscopic methods. 2 showed a moderate inhibitory effect on topoisomerases $\mathrm{I}\left(\mathrm{IC}_{50}\right.$ : $73 \mu \mathrm{M})$ and II ( $\left.\mathrm{IC}_{50}: 98 \mu \mathrm{M}\right)$ without cleavable complexes. Furthermore, $\mathbf{1}$ and $\mathbf{2}$ showed the growth-inhibitory activity toward lung cancer cells LU 65 with $\mathrm{IC}_{50}$ values of 23 and $7 \mu \mathrm{M}$, respectively.
\end{abstract}

Keywords lipopeptides, Fusarium sp., topoisomerase inhibitor, fusaristatins A and B

\section{Introduction}

Endophytic fungi living within plant tissues have proven to be a promising source for the production of structurally novel and pharmacologically active secondary metabolites [1]. As a result of our ongoing efforts to identify new compounds from endophytes, new metabolites were reported from strains of Xylaria sp. YUA-026 [2, 3] and Anthracobia sp.YST-55 [4], which were isolated from unidentified dead branches. In continuing this research, two new cyclic lipopeptides, fusaristatins A (1) and B (2), were isolated from the extract of a rice culture of an endophytic fungus, Fusarium sp. YG-45, which was isolated from the stem of Maackia chinensis (common name: Chinese maackia, family: Leguminosae) collected in Germany. In this report, we describe the characteristics and fermentation of the producing strain, the isolation, structure elucidation and biological characterization of the two compounds.

\section{Results and Discussion}

The producing strain Fusarium sp. YG-45 was grown on white rice under static conditions for three weeks and the culture was then extracted with methanol. The organic extract was concentrated and the aqueous residue extracted with ethyl acetate. This extract was subjected to silica gel and Sephadex LH-20 column chromatography to afford two compounds, 1 and $\mathbf{2}$ (Fig. 1).

1 was obtained as colorless oil. The molecular formula of 1 was determined as $\mathrm{C}_{36} \mathrm{H}_{58} \mathrm{~N}_{4} \mathrm{O}_{7}$ on the basis of HRFABMS, suggesting the presence of ten double bond equivalents. Absorptions at 1727, 1660 and $1531 \mathrm{~cm}^{-1}$ in
Y. Shiono (Corresponding author), M. Tsuchinari, K. Shimanuki, T. Miyajima, T. Murayama, T. Koseki: Department of Bioresource Engineering, Faculty of Agriculture, Yamagata University, Tsuruoka, Yamagata 997-8555, Japan,

E-mail: yshiono@tds1.tr.yamagata-u.ac.jp

H. Laatsch: Institute for Organic and Biomolecular Chemistry, University of Göttingen, Tammannstrasse 2, D-37077, Göttingen, Germany
T. Funakoshi: Kyushu University of Nursing and Social Welfare, 888 Tomio, Tamana 865-0062, Japan

K. Takanami, K. Suzuki: Department of Pharmaceutical Microbiology, Faculty of Medical and Pharmaceutical Sciences, Kumamoto University, Kumamoto 862-0973, Japan 

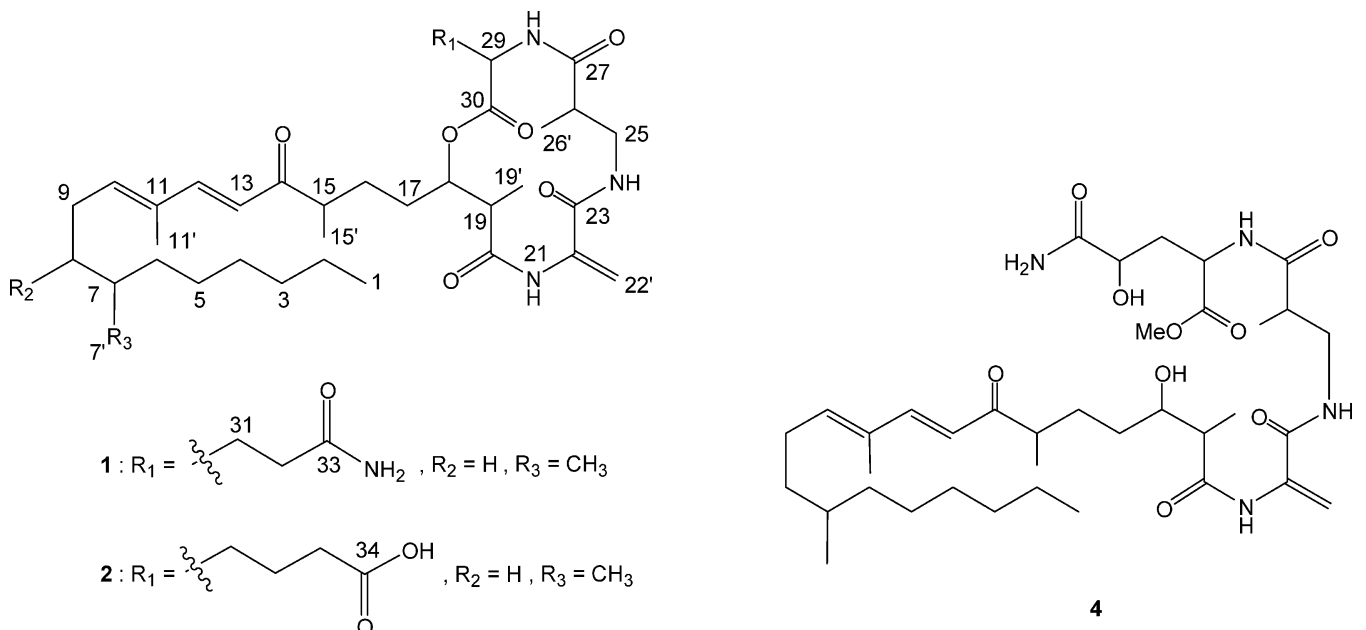

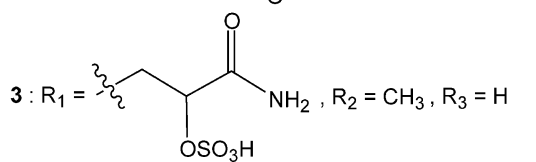

Fig. 1 Structures of fusaristatins A (1), B (2), topostatin (3) and YM-170320 (4).

the IR spectrum were characteristic of esters and amide functions. The UV spectrum of $\mathbf{1}$ revealed an absorption at $285 \mathrm{~nm}$, which suggested a chromophore of conjugated double bonds or a benzene ring in the molecule.

The ${ }^{13} \mathrm{C}$ NMR spectrum $\left(\mathrm{C}_{5} \mathrm{D}_{5} \mathrm{~N}\right)$ showed 36 resolved peaks (Table 1), which were classified into six methyls, twelve $s p^{3}$ methylenes, one $s p^{2}$ methylene, six $s p^{3}$ methines, three $s p^{2}$ methines, two $s p^{2}$ quaternary carbon atoms, and six carbonyl groups by analysis of the DEPT spectra. The connectivity of carbon and proton atoms was established by the HMQC spectrum. The ${ }^{1} \mathrm{H}$ NMR spectrum also supported the molecular formula. It displayed 58 proton signals (Table 1), four signals of low-field resonances at $\delta_{\mathrm{H}} 7.63 \sim 7.69(1 \mathrm{H}, \mathrm{m}), 8.17(2 \mathrm{H}, \mathrm{br} \mathrm{s}), 8.80(1 \mathrm{H}, \mathrm{d}$, $J=7.6 \mathrm{~Hz})$ and $10.18(1 \mathrm{H}, \mathrm{br}$ s) with no HMQC correlations with any carbon signal, which were assignable to amide protons. The ${ }^{1} \mathrm{H}$ NMR spectrum of $\mathbf{1}$ also revealed a large number of aliphatic signals, suggesting the possibility of a lipopeptide-related compound. Analysis of the ${ }^{1} \mathrm{H},{ }^{1} \mathrm{H}-\mathrm{COSY}$ data revealed five partial structures ( $\sim$ V, Fig. 2). A combination of HMQC and $\mathrm{HMBC}$ experiments established the presence of three amino acids, glutamine, dehydroalanine and $\beta$-aminoisobutyric acid. In addition, a $\beta$-hydroxy $\mathrm{C}_{24}$ fatty acid was derived from the NMR data.

A downfield signal (NH-28) of an amide proton showed a COSY correlation with a methine proton signal at $\delta_{\mathrm{H}} 5.05$ (H-29), which in turn coupled with methylene proton resonances at $\delta_{\mathrm{H}} 2.54 \sim 2.59\left(\mathrm{H}_{2}-31\right)$. These signals further coupled with methylene signals at $\delta_{\mathrm{H}} 2.66 \sim 2.71\left(\mathrm{H}_{2}-32\right)$.
The methylene protons $\mathrm{H}_{2}-31$ correlated with three carbons (C-30, C-32 and C-33), and the amide protons $\mathrm{NH}_{2}-34$ correlated with the methylene carbons $\mathrm{C}-32$ and C-33 in the HMBC spectrum (Table 1), suggesting that fragment $\mathrm{V}$ was comprised of a glutamine.

A second amino acid residue was assigned as dehydroalanine by the following evidence. The HMBC correlations of the exo-methylenes $\mathrm{H}_{2}-22^{\prime}$ andx the amide proton $\mathrm{NH}-21$ to $\mathrm{C}-23$ indicated the exo-methylene to be located at $\mathrm{C}-22$.

The last amino acid unit was assigned as $\beta$ aminoisobutyric acid by a methyl doublet $\left[\delta_{\mathrm{H}} 1.30(3 \mathrm{H}, \mathrm{d}\right.$, $\left.J=7.1 \mathrm{~Hz}, \mathrm{H}_{3}-26^{\prime}\right)$ ], which showed $\mathrm{HMBC}$ correlations to the $\beta$-methylene $\mathrm{C}-25$ and the amide carbonyl carbon $\mathrm{C}-27$. In addition, correlations were visible between the $\beta$ methylene protons $\mathrm{H}_{2}-25$ and the carbonyl carbon $\mathrm{C}-27$ in the HMBC spectrum (Table 1).

The remaining part of the molecule, $\mathrm{C}_{24} \mathrm{H}_{40} \mathrm{O}_{3}$, was elucidated as an unsaturated fatty acid derivative by the following NMR data. $\mathrm{HMBC}$ correlations from $\mathrm{H}_{3}-11^{\prime}$ to $\mathrm{C}-10, \mathrm{C}-11$ and $\mathrm{C}-12$, suggested a connection between fragments I and II via an olefinic carbon C-11. The connections between fragments II and III through C-14 were deduced from $\mathrm{HMBC}$ correlations from $\mathrm{H}-13$ to $\mathrm{C}-15$, and $\mathrm{H}-15^{\prime}$ to $\mathrm{C}-14$, respectively. The $(E)$ configurations of two internal double bonds at C-10-C-11 and C-12-C-13 in 1 were determined by the large coupling constant $\left(J_{12,13}=15.7 \mathrm{~Hz}\right)$ and NOE signals between $\mathrm{H}-13$ and $\mathrm{H}_{3}-11^{\prime}$, and between $\mathrm{H}-10$ and $\mathrm{H}-12$. 
Table $1{ }^{1} \mathrm{H}$ - and ${ }^{13} \mathrm{C}-\mathrm{NMR}$ data of fusaristatin $\mathrm{A}(\mathbf{1})$

\begin{tabular}{|c|c|c|c|}
\hline No. & $\delta_{\mathrm{C}}$ & $\delta_{\mathrm{H}}$ & $\mathrm{HMBC}$ \\
\hline 1 & $14.2 \mathrm{q}$ & $0.85(3 \mathrm{H}, \mathrm{t}, 7.0)$ & 2,3 \\
\hline 2 & $22.9 t$ & $1.20 \sim 1.33^{*}$ & \\
\hline 3 & $32.1 \mathrm{t}$ & $1.20 \sim 1.33^{*}$ & \\
\hline 4 & $27.2 \mathrm{t}$ & $1.20 \sim 1.33^{*}$ & \\
\hline 5 & $29.9 t$ & $1.20 \sim 1.33^{*}$ & \\
\hline \multirow[t]{2}{*}{6} & $37.1 \mathrm{t}$ & $1.07 \sim 1.11(1 \mathrm{H}, \mathrm{m})$ & \\
\hline & & $1.20 \sim 1.33^{*}$ & \\
\hline 7 & $32.8 d$ & $1.36 \sim 1.44^{*}$ & \\
\hline $7^{\prime}$ & $19.7 q$ & $0.87(3 \mathrm{H}, \mathrm{d}, 6.4)$ & $6,7,8$ \\
\hline \multirow[t]{2}{*}{8} & $36.5 \mathrm{t}$ & $1.20 \sim 1.33^{*}$ & \\
\hline & & $1.36 \sim 1.44^{*}$ & \\
\hline 9 & $26.9 t$ & $2.13 \sim 2.22(2 \mathrm{H}, \mathrm{m})$ & $7,8,10,11$ \\
\hline 10 & $143.9 \mathrm{~d}$ & $6.00(1 \mathrm{H}, \mathrm{t}, 7.2)$ & $8,12,11^{\prime}$ \\
\hline 11 & $133.5 \mathrm{~s}$ & & \\
\hline $11^{\prime}$ & $12.2 \mathrm{q}$ & $1.80(3 \mathrm{H}, \mathrm{s})$ & $10,11,12$ \\
\hline 12 & $147.9 \mathrm{~d}$ & $7.50(1 \mathrm{H}, \mathrm{d}, 15.7)$ & $10,14,11^{\prime}$ \\
\hline 13 & $123.5 \mathrm{~d}$ & $6.36(1 \mathrm{H}, \mathrm{d}, 15.7)$ & $11,14,15$ \\
\hline 14 & $203.3 s$ & & \\
\hline 15 & $44.3 d$ & $2.95 \sim 3.04(1 \mathrm{H}, \mathrm{m})$ & 14,17 \\
\hline $15^{\prime}$ & $17.2 \mathrm{q}$ & $1.09(3 \mathrm{H}, \mathrm{d}, 6.9)$ & $14,15,16$ \\
\hline \multirow[t]{2}{*}{16} & $28.3 t$ & $1.49 \sim 1.61(1 \mathrm{H}, \mathrm{m})$ & $15,15^{\prime}$ \\
\hline & & $1.88 \sim 2.00^{*}$ & \\
\hline \multirow[t]{2}{*}{17} & $30.1 \mathrm{t}$ & $1.79 \sim 1.85(1 \mathrm{H}, \mathrm{m})$ & \\
\hline & & $1.88 \sim 2.00^{*}$ & \\
\hline 18 & $77.1 \mathrm{~d}$ & $5.36 \sim 5.41(1 \mathrm{H}, \mathrm{m})$ & $16,20,30$ \\
\hline 19 & $44.2 d$ & $2.80 \sim 2.86^{*}$ & \\
\hline $19^{\prime}$ & $15.3 q$ & $1.28(3 \mathrm{H}, \mathrm{d}, 7.1)$ & 19,20 \\
\hline 20 & $173.2 \mathrm{~s}$ & & \\
\hline 21-NH & & $10.18(1 \mathrm{H}, \mathrm{brs})$ & $20,22,23,22^{\prime}$ \\
\hline 22 & $138.9 \mathrm{~s}$ & & \\
\hline \multirow[t]{2}{*}{$22^{\prime}$} & $114.1 \mathrm{t}$ & $5.58(1 \mathrm{H}, \mathrm{s})$ & 22,23 \\
\hline & & $6.18(1 \mathrm{H}, \mathrm{s})$ & 22,23 \\
\hline 23 & $164.8 \mathrm{~s}$ & & \\
\hline 24-NH & & $7.63 \sim 7.69(1 \mathrm{H}, \mathrm{m})$ & 23 \\
\hline \multirow[t]{2}{*}{25} & $42.5 \mathrm{t}$ & $3.70 \sim 3.79(1 \mathrm{H}, \mathrm{m})$ & $23,27,26^{\prime}$ \\
\hline & & $3.82 \sim 3.90(1 \mathrm{H}, \mathrm{m})$ & $23,27,26^{\prime}$ \\
\hline 26 & $42.3 d$ & $2.80 \sim 2.86^{*}$ & \\
\hline $26^{\prime}$ & $15.0 \mathrm{q}$ & $1.30(3 \mathrm{H}, \mathrm{d}, 7.1)$ & $25,26,27$ \\
\hline 27 & $174.5 \mathrm{~s}$ & & \\
\hline 28-NH & & $8.80(1 \mathrm{H}, \mathrm{d}, 7.6)$ & 27,29 \\
\hline 29 & $53.2 \mathrm{~d}$ & $5.05(1 \mathrm{H}, \mathrm{dd}, 14.0,7.6)$ & $27,30,32$ \\
\hline 30 & $171.9 \mathrm{~s}$ & & \\
\hline 31 & $27.4 \mathrm{t}$ & $2.54 \sim 2.59(2 \mathrm{H}, \mathrm{m})$ & $30,32,33$ \\
\hline 32 & $32.4 \mathrm{t}$ & $2.66 \sim 2.71(2 \mathrm{H}, \mathrm{m})$ & 29,33 \\
\hline 33 & $175.4 \mathrm{~s}$ & & \\
\hline $34-\mathrm{NH}_{2}$ & & $8.17(2 \mathrm{H}, \mathrm{br} \mathrm{s})$ & 32,33 \\
\hline
\end{tabular}

Measured in $\mathrm{C}_{5} \mathrm{D}_{5} \mathrm{~N}$, and values in parentheses are coupling constants in $\mathrm{Hz}$.

* Overlapping signals. 


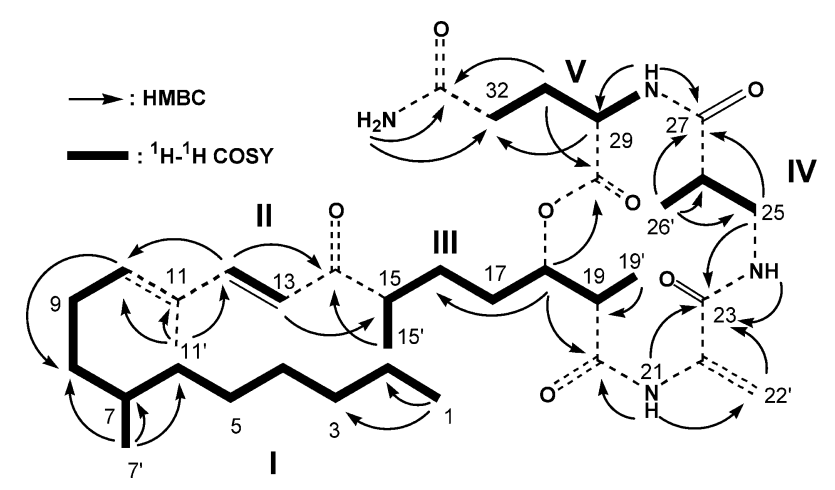

Fig. 2 Selected ${ }^{1} \mathrm{H}-{ }^{1} \mathrm{H}$ COSY and $\mathrm{HMBC}$ correlations for 1 .

The sequence of the three amino acid residues and the $\mathrm{C}_{24}$ unsaturated fatty acid chain unit was determined by HMBC correlations between the amide proton NH-28 of the glutamine and a carbonyl (C-27) of $\beta$-aminoisobutyric acid, between the amide proton $\mathrm{NH}-24$ of $\beta$-aminoisobutyric acid and a carbonyl (C-23) of dehydroalanine, the amide proton (NH-21) of dehydroalanine and a carbonyl (C-20) of the $\mathrm{C}_{24}$ unsaturated fatty acid, and between the oxymethine proton $\mathrm{H}-18$ and the ester carbonyl C-30. Therefore, the structure of 1 was assembled as shown in Fig. 1.

The molecular formula of $\boldsymbol{2}$ was elucidated to be $\mathrm{C}_{37} \mathrm{H}_{59} \mathrm{~N}_{3} \mathrm{O}_{8}$ from the HRFABMS. Inspection of ${ }^{1} \mathrm{H}$ and ${ }^{13} \mathrm{C}$ NMR spectra of $\mathbf{2}$ indicated that most signals in $\mathbf{2}$ were the same as those of $\mathbf{1}$ except for the signals corresponding to the glutamine residue (Tables 1 and 2). In the HMBC spectrum (Table 2) of 2, correlations from $\mathrm{H}_{2}-31$ to $\mathrm{C}-30$, and $\mathrm{H}_{2}-33$ to $\mathrm{C}-31$ and $\mathrm{C}-34$ suggested the presence of an $\alpha$-aminoadipic acid residue instead of glutamine residue in 1. The unambiguous assignments of the signals in the ${ }^{1} \mathrm{H}$ and ${ }^{13} \mathrm{C}$ NMR spectra of 2 (Fig. 1) were finally based on HMBC experiments.

The antimicrobial activities of $\mathbf{1}$ and $\mathbf{2}$ were tested by the agar dilution method. At a concentration of $100 \mu \mathrm{g} / \mathrm{ml}, \mathbf{1}$ and 2 were inactive against Staphylococcus aureus NBRC 13276, Pseudomonas aeruginosa ATCC 15442, Candida albicans ATCC 2019, and Aspergillus clavataus F 318a.

$\mathbf{1}$ and $\mathbf{2}$ were closely related to topostatin (3), a cyclic lipopeptide previously isolated from cultures of Thermomonospora alba strain No. 1520 [5]. It was reported that 3 inhibited the activities of DNA topoisomerases I and II, without cleavable complexes, and was a new type of topoisomerase I and II inhibitors having different structure compared with known topoisomerase I and II inhibitors $[6,7]$.

DNA topoisomerases I and II catalyze the breakage and rejoining of DNA strands to interconvert different topological forms of DNA. Topoisomerases are activated in growing cancer cells, and thus are important targets of anticancer chemotherapeutic agents [8]. Based on the structural analogy with $\mathbf{3}$, we investigated also $\mathbf{1}$ and $\mathbf{2}$ for their topoisomerases I and II inhibitory activities (Table 3 ). The inhibitory activities of both compounds on topoisomerase I were observed through relaxation assays with supercoiled plasmid DNA. Camptothecin was used as a positive control $\left(\mathrm{IC}_{50}: 17 \mu \mathrm{M}\right)$. In the presence of $\mathbf{1}$ $(100 \mu \mathrm{M})$, a relaxation effect was not observed. However, we have found a moderate relaxation inhibitory effect of $\mathbf{2}$ ( $\left.\mathrm{IC}_{50}: 73 \mu \mathrm{M}\right)$ on topoisomerase I from calf thymus glands. The inhibitory effects on the human topoisomerase II were evaluated in the decatenation assay using kinetoplast DNA. Etoposide, a known topoisomerase II inhibitor, was used as a positive control $\left(\mathrm{IC}_{50} 30 \mu \mathrm{M}\right)$. While $\mathbf{1}$ did not show inhibitory activity against topoisomerase II, $\mathbf{2}$ presented a weak inhibition of $\mathrm{IC}_{50} 98 \mu \mathrm{M}$ (Table 3). 3 exhibited inhibition of topoisomerases $\mathrm{I}$ and $\mathrm{II}\left(\mathrm{IC}_{50}: 17 \mu \mathrm{M}\right.$ for topoisomerase $\mathrm{I}$ and $\mathrm{IC}_{50}: 4 \mu \mathrm{M}$ for topoisomerase II), which was stronger than that of the positive control with etoposide. Comparisons of the inhibitory activities of 3 with $\mathbf{1}$ and $\mathbf{2}$ suggests that the presence of sulfate $\left(-\mathrm{OSO}_{3} \mathrm{H}\right)$ at the 32-position of $\mathbf{3}$ may be associated with the potent inhibition of topoisomerases I and II.

Topoisomerase inhibitors of the cleavable complexforming type such as camptothecin and etoposide stabilize the cleavable complex (topoisomerase-DNA reaction intermediate) and inhibit the DNA rejoining reaction of topoisomerase, which is the inhibitory mechanism of the inhibitors, therefore the inhibitors induce nicked or linearized DNA in the cleavage assay [5, 9, 10]. To determine whether $\mathbf{2}$ is an inhibitor of the cleavable complex-forming type or not, cleavage assays were carried out. Camptothecin and etoposide were used as the controls of cleavable complex-forming inhibitors against topoisomerases I and II, respectively. Camptothecin or etoposide induced nicked or linerized DNA with increasing concentrations. On the other hand, 2 could not induce nicked or linearized DNA even at $200 \mu \mathrm{M}$. These results suggest that $\mathbf{2}$ is an inhibitor of the cleavable-nonforming type as well as 3 [5]. 2 may directly act on topoisomerase I and II molecules in earlier step than the formation of the topoisomerase-DNA complex and inhibit the DNA breaking and rejoining reactions by the enzymes.

We studied the anti-tumor effects of $\mathbf{1}$ and $\mathbf{2}$ on human cancer cells, LU 65 and COLO 201. 1 and 2 inhibited the cell growth activity against lung cancer cells LU 65 with $\mathrm{IC}_{50}$ values of $23 \mu \mathrm{M}$ and $7 \mu \mathrm{M}$, respectively. In colon cancer cells COLO 201, both compounds did not have cytotoxic effect at the concentrations up to $100 \mu \mathrm{M}$. Further 
Table $2{ }^{1} \mathrm{H}$ - and ${ }^{13} \mathrm{C}-\mathrm{NMR}$ data of fusaristatin $\mathrm{B}(\mathbf{2})$

\begin{tabular}{|c|c|c|c|}
\hline No. & $\delta_{\mathrm{C}}$ & $\delta_{\mathrm{H}}$ & $\mathrm{HMBC}$ \\
\hline 1 & $14.2 \mathrm{q}$ & $0.88(3 \mathrm{H}, \mathrm{t}, 7.0)$ & 2,3 \\
\hline 2 & $22.9 \mathrm{t}$ & $1.22 \sim 1.29 *$ & \\
\hline 3 & $32.1 \mathrm{t}$ & $1.22 \sim 1.29 *$ & \\
\hline 4 & $27.2 \mathrm{t}$ & $1.22 \sim 1.29 *$ & \\
\hline 5 & $29.9 t$ & $1.22 \sim 1.29^{*}$ & \\
\hline \multirow[t]{2}{*}{7} & $37.1 \mathrm{t}$ & $1.10 \sim 1.12(1 \mathrm{H}, \mathrm{m})$ & \\
\hline & & $1.22 \sim 1.29^{*}$ & \\
\hline 7 & $32.7 \mathrm{~d}$ & $1.40 \sim 1.43^{*}$ & \\
\hline $7^{\prime}$ & $19.6 q$ & $0.88(3 \mathrm{H}, \mathrm{d}, 6.4)$ & $6,7,8$ \\
\hline \multirow[t]{2}{*}{8} & $36.4 \mathrm{t}$ & $1.22 \sim 1.29 *$ & \\
\hline & & $1.40 \sim 1.43^{*}$ & \\
\hline 9 & $26.8 \mathrm{t}$ & $2.17 \sim 2.22^{*}$ & \\
\hline 10 & $144.0 \mathrm{~d}$ & $6.03(1 \mathrm{H}, \mathrm{t}, 7.3)$ & $8,12,11^{\prime}$ \\
\hline 11 & $133.5 \mathrm{~s}$ & & \\
\hline $11^{\prime}$ & $12.2 \mathrm{q}$ & $1.82(3 \mathrm{H}, \mathrm{s})$ & $10,11,12$ \\
\hline 12 & $147.8 d$ & $7.53(1 \mathrm{H}, \mathrm{d}, 15.7)$ & $10,14,11^{\prime}$ \\
\hline 13 & $123.1 \mathrm{~d}$ & $6.38(1 \mathrm{H}, \mathrm{d}, 15.7)$ & $11,14,15$ \\
\hline 14 & $203.1 \mathrm{~s}$ & & \\
\hline 15 & $44.1 \mathrm{~d}$ & $3.04(1 \mathrm{H}, \mathrm{m})$ & \\
\hline $15^{\prime}$ & $17.1 \mathrm{q}$ & $1.11(3 \mathrm{H}, \mathrm{d}, 7.0)$ & $14,15,16$ \\
\hline \multirow[t]{2}{*}{16} & $28.1 \mathrm{t}$ & $1.60 \sim 1.64(1 \mathrm{H}, \mathrm{m})$ & \\
\hline & & $1.96 \sim 2.01^{*}$ & \\
\hline \multirow[t]{2}{*}{17} & $29.7 t$ & $1.81 \sim 1.87(1 \mathrm{H}, \mathrm{m})$ & \\
\hline & & $1.96 \sim 2.01^{*}$ & \\
\hline 18 & $76.7 d$ & $5.43 \sim 5.46(1 \mathrm{H}, \mathrm{m})$ & $16,20,30$ \\
\hline 19 & $44.1 \mathrm{~d}$ & $2.86(1 \mathrm{H}, \mathrm{m})$ & $17,19^{\prime}$ \\
\hline $19^{\prime}$ & $15.4 \mathrm{q}$ & $1.30(3 \mathrm{H}, \mathrm{d}, 7.1)$ & $18,19,20$ \\
\hline 20 & $173.7 \mathrm{~s}$ & & \\
\hline 21-NH & & $10.38(1 \mathrm{H}, \mathrm{brs})$ & $20,23,22^{\prime}$ \\
\hline 22 & $139.2 \mathrm{~s}$ & & \\
\hline \multirow[t]{2}{*}{$22^{\prime}$} & $113.7 t$ & $5.60(1 \mathrm{H}, \mathrm{s})$ & 22,23 \\
\hline & & $6.18(1 \mathrm{H}, \mathrm{s})$ & 22,23 \\
\hline 23 & $164.8 \mathrm{~s}$ & & \\
\hline 24-NH & & $7.78(1 \mathrm{H}, \mathrm{t}, 5.9)$ & 23,25 \\
\hline \multirow[t]{2}{*}{25} & $42.5 \mathrm{t}$ & $3.74(1 \mathrm{H}, \mathrm{ddd}, 13.7,7.6,6.0)$ & $23,26,27,26^{\prime}$ \\
\hline & & $3.94(1 \mathrm{H}, \mathrm{ddd}, 13.7,6.2,4.2)$ & $23,26,27,26^{\prime}$ \\
\hline 26 & $42.4 \mathrm{~d}$ & $2.89(1 \mathrm{H}, \mathrm{m})$ & \\
\hline $26^{\prime}$ & $15.3 q$ & $1.34(3 \mathrm{H}, \mathrm{d}, 7.2)$ & \\
\hline 27 & $174.5 \mathrm{~s}$ & & \\
\hline 28-NH & & $8.69(1 \mathrm{H}, \mathrm{brs})$ & 27,29 \\
\hline 29 & $52.9 d$ & $5.02 \sim 5.06(1 \mathrm{H}, \mathrm{m})$ & $27,30,31,32$ \\
\hline 30 & $171.9 \mathrm{~s}$ & & \\
\hline \multirow[t]{2}{*}{31} & $31.1 \mathrm{t}$ & $2.17 \sim 2.22 *$ & \\
\hline & & $2.26 \sim 2.29(1 \mathrm{H}, \mathrm{m})$ & 30,32 \\
\hline \multirow[t]{2}{*}{32} & $22.1 \mathrm{t}$ & $1.96 \sim 2.01^{*}$ & \\
\hline & & $2.04 \sim 2.10(1 \mathrm{H}, \mathrm{m})$ & 34 \\
\hline 33 & $34.4 \mathrm{t}$ & $2.53 \sim 2.59(2 \mathrm{H}, \mathrm{m})$ & $31,32,34$ \\
\hline 34 & $175.6 \mathrm{~s}$ & & \\
\hline
\end{tabular}

Measured in $\mathrm{C}_{5} \mathrm{D}_{5} \mathrm{~N}$, and values in parentheses are coupling constants in $\mathrm{Hz}$.

* Overlapping signals. 
Table $\mathbf{3}$ Inhibitory activities of $\mathbf{1}, \mathbf{2}, \mathbf{3}$, camptothecin and etoposide against topoisomerases I and II $\left(\mathrm{IC}_{50}, \mu \mathrm{M}\right)$

\begin{tabular}{crrrr}
\hline & \multicolumn{2}{c}{ Topoisomerase I } & & Topoisomerase II \\
\cline { 2 - 4 } Compound & $>100$ & Human placenta & & Human placenta \\
\cline { 2 - 4 } & 73 & $>100$ & $>100$ \\
$\mathbf{1}$ & 17 & $>100$ & 98 \\
$\mathbf{3}$ & 17 & -17 & $>100$ \\
Camptothecin & $>100$ & $>100$ & 30 \\
Etoposide & & & 30 \\
\hline
\end{tabular}

study for the mechanism of the action by $\mathbf{2}$ could be needed to clarify the correlations between growth inhibitory activity in tumor cells LU 65 and the inhibitory activity of topoisomerases I and II in vitro.

An unidentified fungal strain YL-03706F produces compound YM-170320 (4) (Fig. 1) [11], which is an acyclic analogue of $\mathbf{1}$ and $\mathbf{3}$. Interestingly, whereas $\mathbf{4}$ induced moderate morphological changes of a Candida tropicalis mutant, YL-03706F has no inhibitory activity against filamentous fungi. In addition, the strain YL03706F has not previously been reported to produce a cyclic congener, and furthermore, an acyclic analogue such as $\mathbf{4}$ has not been isolated so far from the culture broth of $\mathbf{3}$ producing strains. However, in the biogenesis of the cyclic compounds $\mathbf{1}, \mathbf{2}$ and $\mathbf{3}$, an acyclic form such as $\mathbf{4}$ could be a precursor. In order to clarify the biosynthetic pathway, we are now further studying these new fusaristatin analogues.

\section{Experimental}

\section{General}

Optical rotations were measured with a Horiba model SEPA-300 polarimeter, whereas IR and UV spectra were recorded with JASCO J-20A and Shimadzu UV mini1240 spectrophotometer, respectively. Mass spectra were obtained using a Finngan MAT 95 spectrometer, and ${ }^{1} \mathrm{H}$ and ${ }^{13} \mathrm{C}$ NMR spectra were acquired with a Varian Unity 400 spectrometer, at $400 / 100 \mathrm{MHz}$, respectively. Chemical shifts are given on a $\delta(\mathrm{ppm})$ scale with TMS as an internal standard. Column chromatography was conducted on silica gel 60 (Merck) and Sephadex LH-20 (GE Healthcare). TLC was carried out using precoated silica gel plates $(0.5 \mathrm{~mm}$; Merck and Macherey-Nagel \& Co.), and spots were detected by spraying with $10 \%$ vanillin in $\mathrm{H}_{2} \mathrm{SO}_{4}$ followed by heating, or by UV irradiation. Topoisomerase I from the calf thymus gland and supercoiled pBR322 DNA from
Escherichia coli were purchased from MBI Fermentas. Topoisomerase II from human placenta and kinetoplast DNA from Crithidia fasciculata were purchased from TopoGEN. Camptothecin and etoposide were obtained from Aldrich and Calbiochem, respectively.

\section{Isolation of the Producing Strain}

The fungal strain YG-45 was isolated from the stem of Maackia chinensis collected in Oct. 2005 in the botanical garden in Göttingen, Germany. A twig segment from Maackia chinensis was surface sterilized by successively submersion in $70 \% \mathrm{EtOH}$ for 1 minute, $5.0 \%$ sodium hypochlorite for 5 minutes and $70 \% \mathrm{EtOH}$ for 1 minute, and then rinsed twice with sterile water. The sterilized samples were dried on sterilized paper and cut into $1-\mathrm{cm}$ pieces. The pieces were placed on plates of potato dextrose agar (PDA) containing chloramphenicol (100 mg/l). Successive subculturing of the outgrowing fungi resulted in a pure culture initially coded YG-45. This strain was identified as a Fusarium species by Centraalbureau voor Schimmelcultures (The Netherlands). The strain Fusarium sp. YG-45 has been deposited at the laboratory of the Faculty of Agriculture, Yamagata University, Yamagata, Japan.

\section{Fermentation, Extraction and Isolation}

The fungal strain YG-45 was cultivated on sterilized rice (total $400 \mathrm{~g}, 40 \mathrm{~g} / 500-\mathrm{ml}$ Erlenmeyer flask $\times 10$ ) at $25^{\circ} \mathrm{C}$ for 3 weeks. The moldy rice was extracted $\mathrm{MeOH}$, and the $\mathrm{MeOH}$ extract was concentrated. The resulting aqueous phase was extracted first with $n$-hexane and then EtOAc. The EtOAc extract (5.1 g) was chromatographed on a silica gel column using a stepwise gradient starting from $10 \%$ EtOAc in hexane to $100 \%$ EtOAc. Purification of the eluates was monitored by the characteristic intense blue coloration with $10 \%$ vanillin in $\mathrm{H}_{2} \mathrm{SO}_{4}$ on TLC plates. The $100 \%$ EtOAc fraction $(50.4 \mathrm{mg})$ was further subjected to 
Sephadex LH-20 column chromatography by eluting with $\mathrm{MeOH}$ to afford fractions 1 through 15. Fraction 4 $(22.4 \mathrm{mg})$ was chromatographed on a silica gel column $\left(\mathrm{CHCl}_{3}-\mathrm{MeOH}\right)$ to yield $\mathbf{1}(7.2 \mathrm{mg})$ and $\mathbf{2}(2.2 \mathrm{mg})$.

1: oil; $[\alpha]_{\mathrm{D}}^{20}-35^{\circ}(c 0.11, \mathrm{MeOH})$; UV $\lambda_{\max }^{\mathrm{MeOH}}(\varepsilon) 285$ $(25,000)$; IR $v_{\max }(\mathrm{KBr}) \mathrm{cm}^{-1} 3382,2927,1727,1660$, 1531, 1238, 1172; FAB-MS: $659[\mathrm{M}+\mathrm{H}]^{+}$. HR-FAB-MS: 659.4378 $\left([\mathrm{M}+\mathrm{H}]^{+}, \mathrm{C}_{37} \mathrm{H}_{59} \mathrm{~N}_{4} \mathrm{O}_{7}\right.$, calcd. 659.4385).

2: oil; $[\alpha]_{\mathrm{D}}^{20}-37^{\circ}(c \quad 0.12, \mathrm{MeOH}) ; \mathrm{UV} \lambda_{\max }^{\mathrm{MeOH}}(\varepsilon) 285$ $(25,000)$; IR $v_{\max }(\mathrm{KBr}) \mathrm{cm}^{-1} 3417,2927,1733,1658$, 1531, 1205; FAB-MS: $674[\mathrm{M}+\mathrm{H}]^{+}$. HR-FAB-MS: $674.4375\left([\mathrm{M}+\mathrm{H}]^{+}, \mathrm{C}_{36} \mathrm{H}_{60} \mathrm{~N}_{3} \mathrm{O}_{8}\right.$, calcd. 674.4380).

\section{Relaxation and Cleavage Assays of Topoisomerase I}

The activity of compounds on the relaxation of DNA topoisomerase I (human plasenta) was determined by the measuring the conversion of the supercoiled pBR322 DNA to relaxed form, as described previously [5]. Briefly, each reaction mixture has a total volume of $20 \mu \mathrm{l}$ containing 1 unit topisomerase I (20 units for the cleavage assay) and supercoiled pBR 322 DNA $(0.4 \mu \mathrm{g})$. First, $10 \times$ buffer $(2.0 \mu \mathrm{l})[0.5 \mathrm{M}$ Tris-HCl, (pH 7.5), $1.2 \mathrm{M} \mathrm{KCl}, 0.1 \mathrm{M}$ $\mathrm{MgCl}_{2}, 5 \mathrm{mM}$ EDTA, and $\left.5 \mathrm{mM} \mathrm{DTT}\right], 0.6 \mu \mathrm{g}$ BSA, test compounds with different concentrations, 1 unit of topoisomerase I $(0.05 \mu \mathrm{l})$, and $0.15 \mu \mathrm{g}$ pBR $322 \mathrm{DNA}$ were diluted with ultrapure water to keep the total volume for $20 \mu \mathrm{l}$. Then, this mixture was incubated at $37^{\circ} \mathrm{C}$ for 40 minutes and terminated by adding $5.0 \mu \mathrm{l}$ loading buffer [200 mM Tris (pH 7.5), $200 \mathrm{mM}$ boric acid, $5 \mathrm{mM}$ EDTA (pH 7.5), 50\% glycerol, and 10\% bromophenol blue]. $15 \mu \mathrm{l}$ of the mixture was analyzed on a $1.0 \%$ agarose-gel by running at $50 \mathrm{~V}$ for 1 hour in TBE buffer [100 mM Trisborate buffer ( $\mathrm{pH} 8.5$ ) containing $2.5 \mathrm{mM}$ EDTA]. After electrophoresis, gels were dyed in EtBr solution $(0.5 \%$ $\mathrm{mg} / \mathrm{ml}$ ethidium bromide) for 30 minutes and the supercoiled pBR322 DNA on the gel was measured by a densitometer. For the cleavage assay [5, 10], the reaction mixture was terminated by the addition of $5.0 \mu \mathrm{l}$ of the stop solution containing $5.0 \%$ SDS and $12.5 \mu \mathrm{g}$ proteinase $\mathrm{K}$, thereafter incubated for an additional 30 minutes at $37^{\circ} \mathrm{C}$. Loading buffer was added and the mixture was run into $1.0 \%$ agarose gel containing $\operatorname{EtBr}(0.5 \mu \mathrm{g} / \mathrm{ml})$ at $50 \mathrm{~V}$ for 2 hours. After agarose gel electrophoresis, the nicked pBR322 DNA on the gel was measured by a densitometer.

\section{Decatenation and Cleavage Assays of Topoisomerase II}

The inhibitory activities of the compounds with DNA topoisomerase II was assessed by a decatination reaction of kinetoplast DNA [5]. The reaction mixture contained $50 \mathrm{mM}$ Tris- $\mathrm{HCl}$, (pH 7.5), $0.5 \mathrm{mM}$ ATP, $120 \mathrm{mM} \mathrm{KCl}$, $10 \mathrm{mM} \mathrm{MgCl}_{2}, 0.5 \mathrm{mM}$ EDTA, $0.5 \mathrm{mM}$ DTT, $0.6 \mu \mathrm{g}$ BSA,
$12.8 \mu \mathrm{l}$ test compounds with different concentrations, $0.325 \mu \mathrm{g}$ catenated $\mathrm{kDNA}$, and 1 unit of topoisomerase II in a total volume of $20 \mu \mathrm{l}$. After incubation at $37^{\circ} \mathrm{C}$ for 40 minutes, the mixtures were subjected to electrophoresis on $1.0 \%$ agarose gel $(50 \mathrm{~V})$ for 1 hour. After electrophoresis, the gels were stained with $\mathrm{EtBr}$ solution and decatenated kDNA on the gel was measured by a densitometer. For the cleavage activity [5, 11], 10 units topoisomerase II and supercoiled pBR 322 DNA as substrate were used. After electrophoresis (1.2\% agarose gel containing $0.1 \%$ SDS), the increase of linearized pBR322 DNA was estimated as the stabilizing of cleavable complex by an inhibitor.

\section{Assay for Antimicrobial Activity}

The minimal inhibition concentration (MIC) was determined by the agar dilution method, using nutrient agar for bacteria (Staphylococcus aureus NBRC 13276 and Pseudomonas aeruginosa ATCC 15442), Sabouraud agar for Candida albicans ATCC 2019 and PD agar for Aspergillus clavatus $\mathrm{F} 318 \mathrm{a}$. Bioassay procedure was the same as in article [2].

\section{Cell Lines and Cell Culture}

The COLO 201 human colon carcinoma cell line and human lung carcinoma cell line LU 65 were obtained from Japanese Cancer Research Resources Bank. Cells were cultured in medium with RPMI 1640 (Nissui Co., Japan) containing 10\% fetal bovine serum (HyClone Inc., USA) and penicillin/streptomycin (Invitrogen Co., USA) at $37^{\circ} \mathrm{C}$ in a humidified atmosphere of $5.0 \% \mathrm{CO}_{2}$ in air.

\section{Cell Growth Assay}

The cell viability was assessed with 4-[3-(2-methoxy-4nitrophenyl)-2-(4-nitro-phenyl)-2H-5-tetrazolio]-1,3benzene disulfonate sodium (WST-8), a tetrazolium salt, using a commercially available kit (Cell Counting Kit-8; Dojindo Laboratories, Kumamoto, Japan). In brief, human lung carcinoma cells (LU 65, $5 \times 10^{3}$ cells $/ \mathrm{ml}$ ) were seeded in $270 \mu \mathrm{l}$ of culture medium/well in $96-$ well plates. Then, $30 \mu \mathrm{l}$ of test sample dissolved in aqueous DMSO at various concentrations were added and then incubated in a 5.0\% $\mathrm{CO}_{2}$ incubator at $37^{\circ} \mathrm{C}$ for 72 hours. The last concentration of DMSO was $10 \%$ or less. At the end of the incubation, $100 \mathrm{ml}$ of each cultured cell was transferred the other 96-well plates and $10 \mu \mathrm{l}$ of WST- 8 assay solution was added per well and incubated at $37^{\circ} \mathrm{C}$ in humidified air supplemented with $\mathrm{CO}_{2}$ for an additional 4 hours. The amount of formazan formed was measured at an optical density of $450 \mathrm{~nm}$ using a microplate reader and the cell viability was expressed as a percentage of the untreated control. The $\mathrm{IC}_{50}$ values were determined 
by the extrapolation of the dose-response viability curves. 5 -Fluorouracil was used as positive control $\left(\mathrm{IC}_{50}\right.$ values of $1.0 \mu \mathrm{M})$.

\section{Cell Cytotoxicity Assay}

Human colon carcinoma cells COLO $201\left(1 \times 10^{5}\right.$ cells $\left./ \mathrm{ml}\right)$ were seeded in $270 \mu \mathrm{l}$ of culture medium/well in 96-well plates. The cells were treated with $30 \mu \mathrm{l}$ of different concentrations of the test compounds and were incubated at $37^{\circ} \mathrm{C}$ for 72 hours. Cytotoxicity was measured using WST8 method similar to that in the case of cell growth assay.

Acknowledgements We would like to thank Ms. F. Lissy, University of Göttingen, for microbial assistance, Dr. H. Frauendorf and Mr. R. Machinek, University of Göttingen, for spectral measurements. This work was supported in part by Ministry of Education, Culture, Sports, Science and Technology, Japan.

\section{References}

1. Gunatilaka AAL. Natural products from plant-associated microorganisms: distribution, structural diversity, bioactivity, and implications of their occurrence. J Nat Prod 69: 509-526 (2006)

2. Shiono Y, Murayama T, Takahashi K, Okada K, Katohda S, Ikeda M. Three oxygenated cyclohexenone derivatives, produced by an endophytic fungus. Biosci Biotechnol Biochem 69: 287-292 (2005)

3. Shiono Y, Murayama T. New eremophilane-type sesquiterpenoids, eremoxylarins A and B from xylariaceous endophytic fungus YUA-026. Z Naturforsch 60b: 885-890 (2005)

4. Shiono Y. Anthracobic acids A and B, two polyketides, produced by an endophytic fungus Anthracobia sp. Chem Biodivers 3: 217-223 (2006)

5. Suzuki K, Nagao K, Monnai Y, Yagi A, Uyeda M. Topostatin, a novel inhibitor of topoisomerases I and II produced by Thermomonospora alba strain No. 1520. I. Taxonomy, fermentation, isolation and biological activities. J Antibiot 51: 991-998 (1998)

6. Suzuki K, Yahara S, Kido Y, Nagao K, Hatano Y, Uyeda M. Topostatin, a novel inhibitor of topoisomerases I and II produced by Thermomonospora alba strain No. 1520. II. Physico-chemical properties and structure elucidation. J Antibiot 51: 999-1003 (1998)

7. Suzuki K, Yamaizumi M, Tateishi S, Monnai Y, Uyeda M. Topostatin, a novel inhibitor of topoisomerases I and II produced by Thermomonospora alba strain No. 1520. III. Inhibitory properties. J Antibiot 52: 460-465 (1999)

8. Li TK, Liu LF. Tumor cell death induced by topoisomerasetargeting drugs. Ann Rev Pharmacol Toxicol 41: 53-77 (2001)

9. Yamashita Y, Kawada S, Fujii N, Nakano H. Induction of mammalian DNA topoisomerase II dependent DNA cleavage by antitumor antibiotic streptonigrin. Cancer Res 50: 5841-5844 (1990)

10. Hsiang YH, Hertzberg R, Hecht S, Lui LF. Camptothecin induces protein-linked DNA breaks via mammalian DNA topoisomerase I. J Biol Chem 260: 14873-14878 (1985)

11. Sugawara T, Tanaka A, Tanaka K, Nagai K, Suzuki K, Suzuki T. YM-170320, a novel lipopeptide antibiotic inducing morphological change of colonies in a mutant of Candida tropicalis pK233. J Antibiot 51: 435-438 (1998) 